\title{
Effect of Frequency of Application on Response of Guinea Grass to Nitrogen Fertilization ${ }^{1}$
}

\author{
José Vicente-Chandler, Servando Silva, and Jacinto Figarella ${ }^{2}$
}

\section{INTRODUCTION}

The effects of nitrogen fertilization on yield and composition of tropical grasses have received considerable attention in Puerto Rico. Vicente, Silva, and Figarella $(5,6)^{3}$ found that Napier, Guinea, Pangola, and Para grasses responded in yield and protein content to nitrogen applications up to 800 pounds per acre yearly in the humid coastal area, and Caro, Vicente, and Figarella ( 1 ) determined that yields and protein contents of these grasses increased rapidly with nitrogen rates up to at least 400 pounds per acre yearly in the humid mountain region. Vicente and Figarella (4) showed that the application of 100 pounds of nitrogen per acre to unirrigated Guinea grass on the semiarid south coast increased yields by about onethird, with no further increase resulting from heavier applications of this nutrient.

Little, Vicente, and Abruña (2) concluded that yields and protein contents of irrigated Napier and Guinea grasses increased with nitrogen rates up to 800 pounds per acre yearly. Rodríguez (3) demonstrated that, with 50 pounds of nitrogen applied over each 3-month harvest interval, to a total of 200 pounds per acre yearly, the highest yields of Guinea grass were obtained when all the fertilizer was applied immediately after cutting. The grass attained a maximum nitrogen content when all the fertilizer was applied 9 weeks after cutting.

The present experiments were carried out to determine the effect of frequency of application on the response of Guinea grass to nitrogen fertilizer under both cutting and simulated-grazing management.

\section{MATERIALS AND METHODS}

The experiments were carried out at Río Piedras on deep, red, acid Fajardo clay, the surface 6 inches of which averaged 3.2 percent of organic matter, 0.17 percent of nitrogen, and 12.1 m.e. of exchange capacity per $100 \mathrm{gm}$. of soil. Annual rainfall ranged from about 70 to 100 inches during the course of the experiments.

1 This work was carried out cooperatively between the Soil and Water Conservation Research Division, Agricultural Research Service, USDA, and the Agricultural Experiment Station, University of Puerto Rico, Río Piedras, P.R.

2 Soil Scientist, Physical Science Technician, and Chemist, USDA, respectively, stationed at Rfo Piedras, P.R.

Italic numbers in parentheses refer to Literature Cited, pp. 348-9. 
The upper 6 inches of soil was limed to about $\mathrm{pH} 6.0$ and blanket additions of 200 pounds of phosphoric acid, as 20-percent superphosphate, and 400 pounds of potassium, as potassium chloride, per acre, were made annually to all plots. Nitrogen was applied as ammonium sulfate.

All combinations of the treatments were tested using a split-plot design with frequency of application as the main plots and nitrogen rates as the subplots. All treatments were replicated three times. Subplots were 1/200 acre in size, surrounded by ditches to prevent fertilizer from washing into adjoining plots. Yields of dry matter and crude-protein content $(\mathrm{N} \times$ 6.25) of the forage were determined at each harvest.

EXPERIMENT NO. 1-SPLITTING APPLICATIONS BETWEEN CUTTINGS

Time of application: Fertilizer applied 1, immediately after each cutting; 2,25 days after each cutting; and 3 , one-half immediately after each cutting and remainder 25 days later. One-sixth of the annual rate was applied during each 60-day harvest interval, throughout the 1-year course of the experiment.

Nitrogen rates $-0,200,400,800$, and 1,600 pounds per acre yearly.

EXPERIMENT NO. 2-FREQUENCY OF APPLICATIONS

WITH SIMULATED GRAZING

Number of applications: Nitrogen and potassium fertilizer were applied 1 , after each harvest with 8 applications yearly; 2 , after every other harvest with 4 applications yearly; and 3, after every fourth harvest with 2 applications yearly. Forage was harvested by simulated grazing every 45 days over a 2-year period.

Nitrogen rates $-0,200,400,600$, and 800 pounds per acre yearly.

\section{RESULTS AND DISCUSSION}

In both experiments yields varied considerably with season of the year, with lowest productivity during the winter months of lower rainfall and shorter, slightly cooler days.

EXPERLMENT NO. 1

Figure 1 shows that, irrespective of time of application, Guinea grass responded strongly in yield to nitrogen applications up to 800 pounds per acre yearly, while the protein content of the forage increased with nitrogen rates up to 1,600 pounds.

Figure 1 also shows that with nitrogen rates of up to 800 pounds per acre yearly, Guinea grass produced its highest yields when the fertilizer was applied immediately after cutting, and lowest yields when it was applied 25 days after cutting. Splitting the fertilizer application resulted 
in yields intermediate between these two. Protein content was highest when the fertilizer was applied 25 days after cutting, owing to the concentrating effect of lower yields in the presence of a uniform quantity of nitrogen.

Table 1 shows that more of the fertilizer nitrogen was recovered in the Guinea grass forage at all rates when the fertilizer was applied immediately after cutting. Recovery dropped off considerably at the 1,600-pound nitrogen rate.

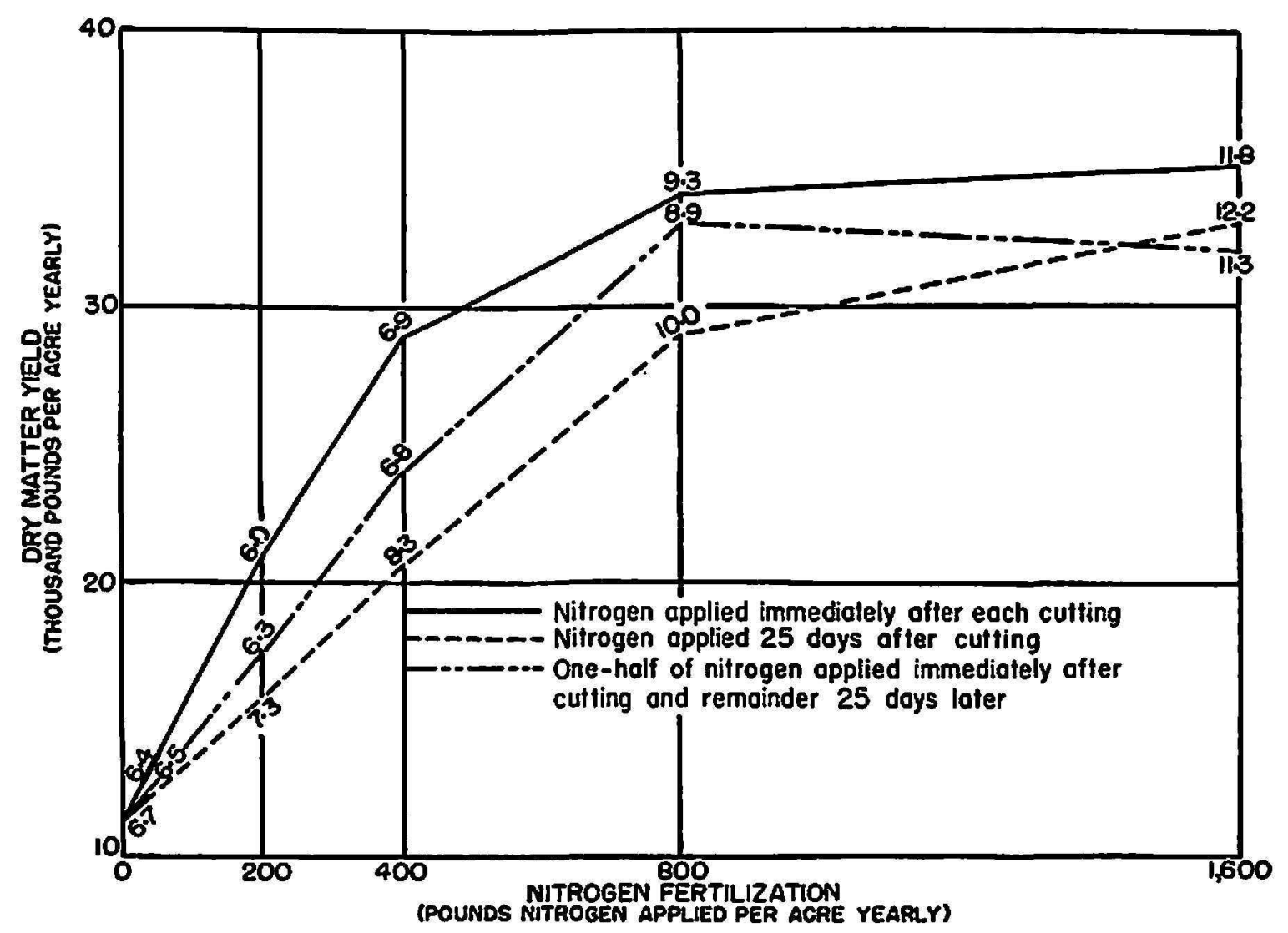

Frg. 1.-Effect of splitting fertilizer applications between cuttings on the response of Guinea grass to nitrogen fertilization. The grass was cut every 60 days over a 1-year period. The numbers indicate the percentage protein content.

It can be concluded that there is no advantage to delaying or splitting nitrogen applications to Guinea grass when optimum cutting intervals of about 60 days (6) are used.

\section{EXPERIMENT NO. 2}

Table 2 shows that, regardless of frequency of application, yields and protein contents of the forage increased with nitrogen rates up to 800 pounds per acre yearly.

Table 2 also shows that annual yields and protein contents of Guinea grass were similar whether the nitrogen was applied in 8,4 , or 2 applica- 
tions yearly. Recovery of fertilizer nitrogen as protein in the forage also was not affected appreciably by frequency of application.

However, figure 2 shows that seasonal yields and protein contents of the forage varied more widely when nitrogen was applied at every fourth

TABLE 1.-The effect of splitting applications between cuttings, and of nitrogen rates, on percentage recovery of fertilizer nitrogen

by Guinea grass over a 1-year period

\begin{tabular}{l|c|c|c|c|c}
\hline \multirow{2}{*}{ Time nitrogen was applied } & \multicolumn{2}{|c|}{$\begin{array}{c}\text { Recovery of fertilizer nitrogen applied at } \\
\text { annual rates shown (pounds) }\end{array}$} & \multirow{2}{*}{ Average } \\
\cline { 2 - 4 } & 200 & 400 & 800 & 1,600 & \\
\hline Immediately after each cutting & 46.0 & 54.5 & 51.2 & 34.7 & 46.6 \\
25 days after cutting & 37.7 & 41.3 & 46.0 & 34.2 & 39.8 \\
$\begin{array}{l}\text { Half immediately after cutting and } \\
\text { remainder 25 days later }\end{array}$ & 36.0 & 39.5 & 45.3 & 29.6 & 37.6 \\
\hline
\end{tabular}

TABLE 2.-The effect of frequency of application and of nitrogen rates on yield and protein content of Guinea grass harvested every 46 days by simulated grazing over a \&-year period

\begin{tabular}{|c|c|c|c|c|c|c|c|c|}
\hline \multirow{2}{*}{$\begin{array}{l}\text { Nitrogen applied } \\
\text { per acre yearly } \\
\text { (pounds) }\end{array}$} & \multicolumn{4}{|c|}{$\begin{array}{l}\text { Dry forage produced per acre } \\
\text { yearly with nitrogen applied in } \\
\text { number of applications shown }\end{array}$} & \multicolumn{4}{|c|}{$\begin{array}{l}\text { Crude-protein content of forage } \\
\text { with nitrogen applied in number } \\
\text { of applications shown }\end{array}$} \\
\hline & 8 & 4 & 2 & Average & 8 & 4 & 2 & Average \\
\hline & Pounds & Pounds & Pounds & Pounds & Percent & Percent & Percent & Percent \\
\hline 0 & 5,996 & 6,719 & 5,702 & 6,139 & 7.8 & 7.7 & 7.9 & 7.8 \\
\hline 200 & 13,911 & 18,126 & 14,267 & 15,435 & 7.8 & 8.3 & 8.5 & 8.2 \\
\hline 400 & 22,584 & 22,608 & 21,863 & 22,352 & 8.7 & 9.5 & 9.6 & 9.3 \\
\hline 600 & 28,022 & 28,892 & 29,573 & 28,829 & 10.6 & 10.6 & 9.9 & 10.4 \\
\hline 800 & 32,562 & 31,222 & 30,630 & 31,471 & 11.2 & 12.1 & 12.1 & 11.8 \\
\hline Average & 20,615 & 21,513 & 20,407 & & 9.2 & 9.6 & 9.6 & \\
\hline
\end{tabular}

cutting in two applications yearly. With such infrequent applications, yields and protein contents were high at the two harvests following fertilization, but dropped off during the third and fourth harvests after fertilization.

Figure 3 shows that nitrogen and potassium uptake by Guinea grass also was more uniform with frequent fertilization. There was a sharp decrease in uptake of these nutrients during the third and fourth cuttings after fertilization with two applications yearly, and a slightly lower uptake over 
the second harvest period when fertilizer was put on at every other cutting (4 times yearly). Percentage nitrogen and potassium content of the forage followed the same trend as total uptake. However, number of applications had no marked effect on the total quantity of these nutrients removed annually.

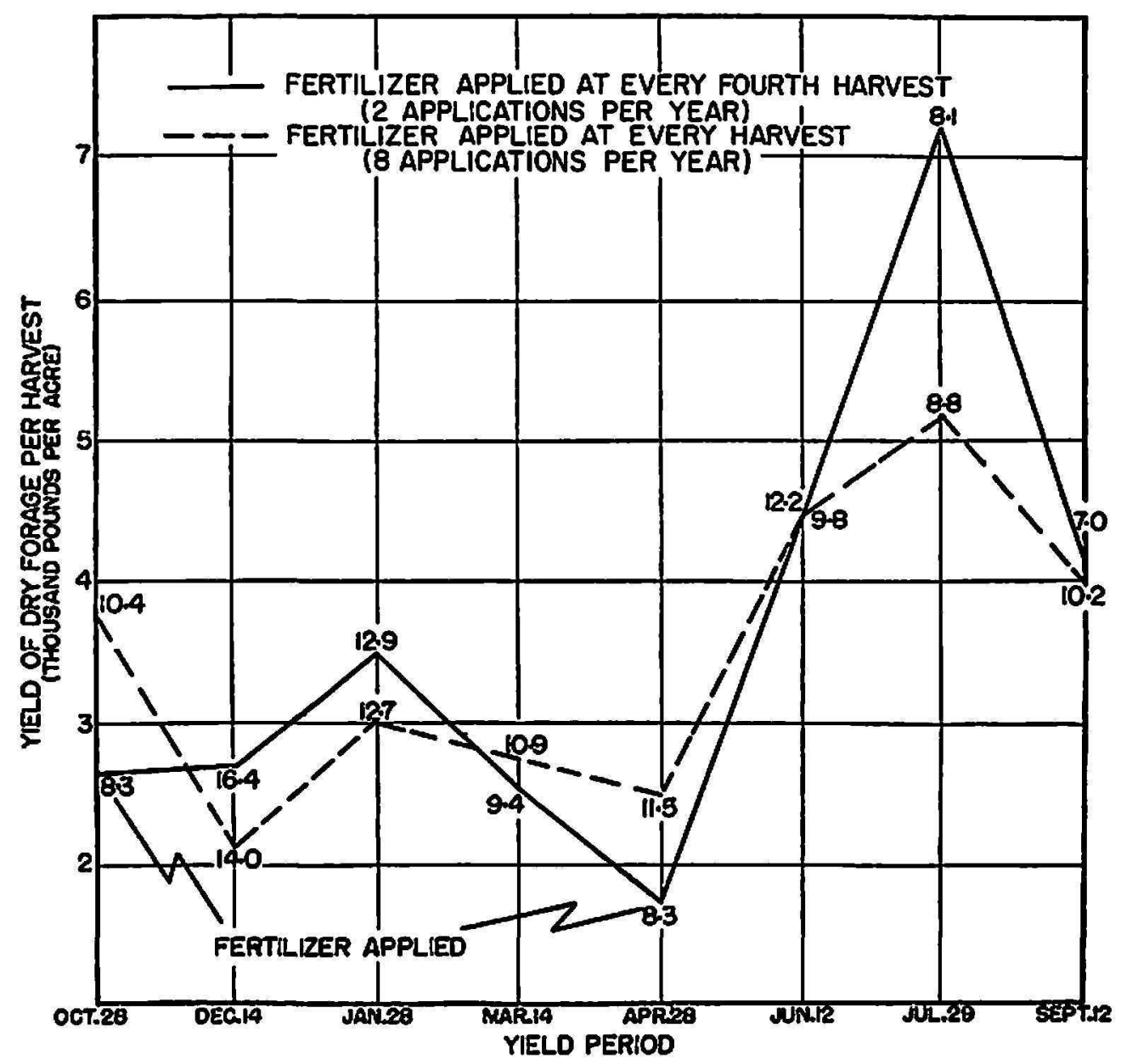

Fig. 2.-Effect of frequency of application of fertilizer on the seasonal yields and protein contents of Guinea grass harvested every 45 days by simulated grazing. The numbers indicate the percentage protein content of the forage. Two tons of 15-5-12 were applied per acre annually. All values are averages of 2 equal yield periods over 2 successive years.

In addition to the undesirably higher variability in seasonal yields and protein content of the forage, there is danger, particularly during dry weather, of damage by burning if heavy annual fertilizer rates are used in only two applications. On the other hand, it is expensive to apply nitrogen too frequently and little is gained by it.

It can be concluded that it is best to apply nitrogen to Guinea grass harvested by grazing in about four applications yearly. 


\section{SUMMARY}

The effect of frequency of application on the response of Guinea grass to nitrogen fertilization with cutting and simulated grazing management was studied in the humid coastal region of Puerto Rico.

Guinea grass responded strongly in yield and protein content to nitrogen

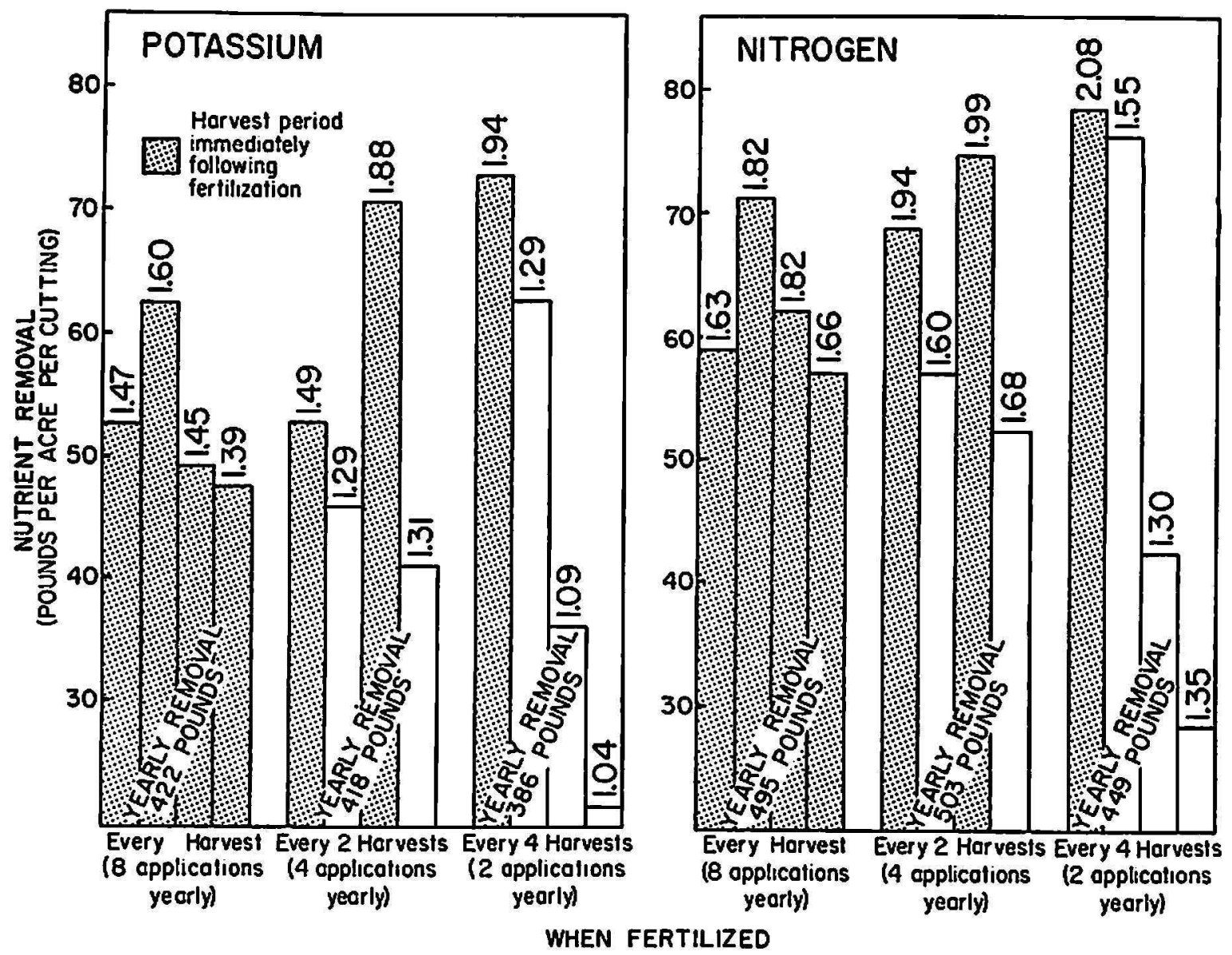

Fig. 3.-Effect of frequency of fertilizer applications on the nitrogen and potassium removal in Guinea grass forage over successive harvests after fertilization, through the second year of experimentation. The numbers indicate the percentage nitrogen or potassium content of the forage. Two tons of 15-5-12 were applied per acre annually and the grass was harvested every $\mathbf{4 5}$ days by simulated grazing.

applications up to 800 pounds per acre yearly, regardless of frequency of application or harvest procedure.

When cut every 60 days, Guinea grass produced its highest yields and recovered more of the fertilizer nitrogen when it was applied immediately after cutting. Its lowest yields occurred when nitrogen was applied 25 days after cutting. Splitting the applications resulted in yields intermediate between these two.

Under grazing management annual yields and protein content of the 
forage were similar whether the nitrogen was used in eight, four, or two applications yearly. However, seasonal yields and protein and potassium content of the forage varied more widely when there were two applications only of fertilizer yearly.

It appears best to apply nitrogen to Guinea grass immediately after each cutting and to make about four applications a year to Guinea grass pastures.

\section{RESUMEN}

Se estudió qué efecto tuvo el número de aplicaciones de abono sobre la yerba de Guinea y cómo respondió esta yerba al nitrógeno bajo condiciones de corte y pastoreo simulado en la región húmeda de Puerto Rico.

El rendimiento y contenido de proteína de la yerba Guinea aumentó según se aumentaron las cantidades de nitrógeno hasta 800 libras por cuerda por año, irrespectivamente del número de aplicaciones, o del método usado para cosecharla.

Bajo corte, la yerba produjo un mayor rendimiento y recobró más el nitrógeno cuando éste se aplicó inmediatamente después de cortarse la yerba cada 60 días. Los rendimientos fueron más bajos cuando el nitrógeno se aplicó 25 días después del corte. Cuando se dividió el nitrógeno para aplicarse en dos ocasiones de un corte a otro, se obtuvieron rendimientos que fluctuaron entre el extremo de mayor producción y el de menor producción.

Bajo pastoreo simulado, el rendimiento anual y el contenido de proteína de la yerba Guinea fué similar cuando el nitrógeno se aplicó en 2, 4, u 8 aplicaciones anualmente. Sin embargo, el rendimiento y el contenido de proteína y potasio del forraje fueron más variables a través del año cuando se aplicó el nitrógeno en sólo dos ocasiones. Además, la yerba puede quemarse cuando se hacen grandes aplicaciones anuales de nitrógeno usando la práctica de sólo dos aplicaciones.

Puede concluirse que la yerba Guinea debe abonarse inmediatamente después de cada corte y que los pastos de esta yerba deben abonarse alrededor de 4 veces al año.

\section{LITERATURE CITED}

1. Caro-Costas, R., Vicente-Chandler, J., and Figarella, J., The yields and composition of five grasses growing in the humid mountains of Puerto Rico as affected by nitrogen fertilization, season, and harvest procedure, J. Agr. Univ. P.R. 44 (3) $107-19,1960$.

2. Little, S., Vicente-Chandler, J., and Abruña, F., Yield and protein content of irrigated Napier grass, Guinea grass, and Pangola grass, as affected by nitrogen fertilization, Agron. J. 51 (2) 111-3, 1959.

3. Rodriguez, J. P., Effect of nitrogen applications on the yields and composition of forage crops, J. Agr. Univ. P.R. 33 (3) 98-117, 1949. 
4. Vicente-Chandler, J., and Figarella, J., Growth characteristics of Guinea grass on the semiarid south coast of Puerto Rico and the effect of nitrogen fertilization on forage yields and protein content, J. Agr. Univ. P.R. 42 (3) 151-60, 1958.

5. Vicente-Chandler, J., Figarella, J., and Silva, S., Effects of nitrogen fertilization and frequency of cutting on the yield and composition of Pangola grass in Puerto Rico, J. Agr. Univ. P.R. 46 (1) 37-45, 1961.

6. Vicente-Chandler, J., Silva, S., and Figarella, J., The effect of nitrogen fertilization and frequency of cutting on the yield and composition of three tropical grasses, Agron.J. 61 (4) 202-6, 1959. 